\title{
Genetic Variability for Yield and Yield Components Characters in Bacterial Blight and Blast Resistance Genes Introgressed Backcross Populations in Rice
}

\section{Ponnaiah Govintharaj*, Shalini Tannidi, Manonmani Swaminathan, Robin Sabariappan, Vishnu Varthini Nachimuthu, Karthika Gunasekaran and Balaji Aravindhan}

\author{
Department of Plant Breeding and Genetics, Centre for Plant Breeding and Genetics, \\ Tamil Nadu Agricultural University, Coimbatore-641003, Tamil Nadu, India \\ *Corresponding author
}

\begin{tabular}{|c|c|}
\hline & A B S T R A C T \\
\hline & An experiment was framed to study the variability, nature of gene action and number of \\
\hline Keywords & $\begin{array}{l}\text { genes controlling the characters in bacterial blight and blast resistance genes introgressed } \\
\text { three backcross population in rice. Mean variation was high for number of grains and plant }\end{array}$ \\
\hline $\begin{array}{l}\text { Rice bacterial } \\
\text { blight, }\end{array}$ & $\begin{array}{l}\text { height for all the crosses. The characters like plant height, number of productive tillers and } \\
\text { number of grains were showed complementary gene interaction for all back cross }\end{array}$ \\
\hline Rice blast, & population. While for thousand grain weight and single plant yield were explained \\
\hline $\begin{array}{l}\text { Skewness, } \\
\text { Kurtosis. }\end{array}$ & $\begin{array}{l}\text { complementary gene interactions in two backcross populations. Selection on these traits } \\
\text { would obtain low genetic advance than expected. Panicle length in two crosses and }\end{array}$ \\
\hline Article Info & $\begin{array}{l}\text { thousand grain weight and single plant yield in one cross was showed duplicate gene } \\
\text { interaction suggests that selection would be effective to gain higher genetic advance than }\end{array}$ \\
\hline $\begin{array}{l}\text { Accepted: } \\
\text { 05 January } 2017 \\
\text { Available Online: } \\
\text { 10 February } 2017\end{array}$ & $\begin{array}{l}\text { expected. Kurtosis for plant height and panicle length was influenced by only few genes } \\
\text { for all crosses, whereas number of productive tillers and number of grains were controlled } \\
\text { by few genes for at least two crosses. Platykurtic distribution was prevalent in most of the } \\
\text { characters in all crosses. Leptokurtic distribution was found in the cross TNAU CMS } 2 \mathrm{~B} \times \\
\text { (TNAU CMS } 2 \mathrm{~B} \times \text { Zenith) for number of grains, suggesting that controlled by fewer }\end{array}$ \\
\hline & \\
\hline
\end{tabular}

\section{Introduction}

Rice is one of most important cereal stable food crop in the world, nearly 2.7 billion livelihoods depends on it (Tannidi et al., 2016). Variability is an important and basic requirement in any breeding programme. Hybridization between genetically diverse parental lines with selection may result huge variation. The skewness and kurtosis statistical analysis provides the information about nature of gene action (Fisher et al., 1932) and number of genes controlling the trait (Robson, 1956).
Generally, skewed distribution of the characters implies that the control of nonadditive type of gene effects and influenced by environmental variables. Positive skewness explained the complementary gene action whereas, negative skewness related to duplicate (additive $\times$ additive) gene effects (Kiran, 2012; Malikarjuna, 2013; Vishnu et al., 2014; Vanitha et al., 2016). Moreover, genes controlling characters with skewed distribution leads to be predominantly dominant irrespective of increasing or 
decreasing genes effect of the characters (Pooni et al., 1997). Positive kurtosis of the characters indicated that presence of gene interactions while for negative sign of kurtosis or near to zero leads the absence of gene interactions (Kotch et al., 1992). The leptokurtic and platykurtic distribution of the characters are controlled by fewer and large number of genes, respectively. The present study aimed to study the variability, nature of gene action and number of genes controlling the characters in bacterial blight and blast resistance genes introgressed three backcross population in rice.

\section{Materials and Methods}

An experimental material comprised of bacterial blight resistance genes governed two backcross population and one blast resistance gene governed backcross population. The backcross populations were grown in Department of Rice, Tamil Nadu Agricultural University, Coimbatore, India. Six agromorphological characters like plant height, number of productive tillers, panicle length, number of grains, thousand grain weight and single plant yield were recorded on the basis of single plant. Statistical analysis was performed in Microsoft Excel 2007 (Microsoft Corp., Redmond, WA, USA).

\section{Results and Discussion}

The statistical parameters i.e. maximum, minimum, mean, standard deviation, variance, standard error, skewness and kurtosis for three set of backcrosses were given in table 1, 2 and 3 .

\section{CB 87 R $\times$ IRBB 60}

Greater amount of variability was present in CB $87 \mathrm{R} \times$ IRBB 60 for all studied characters. Among all, thousand grain weight showed substantial variation with the mean (74.00-
122.00) followed by plant height (76.00-50.00 $\mathrm{cm})$. This finding gets supported with Govintharaj et al., (2016) and Ponnaiah Govintharaj et al. (2016). Negative skewness was found all the studied characters except plant height, number of productive tillers and number of grains. This finding concluded that single plant yield showed complementary gene action and other traits were showed duplicate gene action. This finding get supported with (Kiran et al., 2013; Vishnu et $a l ., 2014)$ for the characters of number of productive tillers and single plant was positive skewness and, negative skewness for plant height and number of grains. The positive kurtosis was found only in thousand grain weight and single plant yield were controlled by cumulative genes, and negative for all other characters controlled by few genes. This finding suggests that characters were platykurtic nature indicating that low phenotypic variability for the cross (Vishnu et al., 2014; Kiran, 2012). Moreover, negative skewness and platykurtic distribution for the traits indicated that these evolved from dominance and dominance based duplicate gene action, which helps to conserve the individual plants from deleterious alleles arising from existing variability (Roy, 2000).

\section{CB 174 R $\times$ IRBB60}

Mean variation was high for number of grains (90.00-146.00) followed by plant height (89.00-127.00 cm). Skewness was positive sign for all studied characters. This finding was resulted for characters were showed duplicate gene interaction and explaining that low performer than average of the population. Positive kurtosis was noticed only for thousand grain weight influenced by more number of genes and others characters were governed by few genes, suggesting platykurtic distribution, suggesting that low agronomical variability for the cross (Vishnu et al., 2014). 
Table.1 Descriptive statistics in $\mathrm{BC}_{1} \mathrm{~F}_{1}$ cross $\mathrm{CB} 87 \mathrm{R} \times \mathrm{IRBB} 60$

\begin{tabular}{|c|c|c|c|c|c|c|c|c|}
\hline \multirow{2}{*}{ Variables } & \multirow{2}{*}{ Mean } & \multicolumn{2}{|c|}{ Range } & \multirow{2}{*}{$\begin{array}{c}\text { Standard } \\
\text { Deviation }\end{array}$} & \multirow{2}{*}{ Variance } & \multirow{2}{*}{$\begin{array}{l}\text { Standard } \\
\text { Error }\end{array}$} & \multirow{2}{*}{ Skewness } & \multirow{2}{*}{ Kurtosis } \\
\hline & & Max. & Min. & & & & & \\
\hline $\mathrm{PH}$ & 82.32 & 90.00 & 76.50 & 4.07 & 16.59 & 11.88 & 0.29 & -1.22 \\
\hline NPT & 10.10 & 16.00 & 6.00 & 2.91 & 8.48 & 1.46 & 0.63 & -0.67 \\
\hline PL & 19.61 & 25.50 & 12.00 & 3.21 & 10.28 & 2.83 & -0.41 & -0.08 \\
\hline NG & 94.56 & 122.00 & 74.00 & 14.16 & 200.63 & 13.65 & 0.52 & -0.91 \\
\hline TGW & 20.07 & 25.80 & 11.20 & 2.55 & 6.51 & 2.90 & -0.94 & 2.44 \\
\hline SPY & 19.80 & 24.78 & 12.31 & 2.64 & 6.97 & 2.86 & -0.50 & 0.15 \\
\hline
\end{tabular}

Table.2 Descriptive statistics in $\mathrm{BC}_{1} \mathrm{~F}_{1}$ cross $\mathrm{CB} 174 \mathrm{R} \times \mathrm{IRBB} 60$

\begin{tabular}{|c|c|c|c|c|c|c|c|c|}
\hline \multirow{2}{*}{ Variables } & \multirow{2}{*}{ Mean } & \multicolumn{2}{|c|}{ Range } & Standad & \multirow{2}{*}{$\begin{array}{c}\text { Sariance } \\
\text { Deviation }\end{array}$} & $\begin{array}{c}\text { Standard } \\
\text { Error }\end{array}$ & Skewness & Kurtosis \\
\cline { 3 - 9 } & & Max. & Min. & & & \\
\hline PH & 108.26 & 129.00 & 89.00 & 11.70 & 137.01 & 14.73 & 0.10 & -1.20 \\
\hline NPT & 10.57 & 15.00 & 8.00 & 2.07 & 4.29 & 1.44 & 0.52 & -0.88 \\
\hline PL & 22.34 & 27.50 & 18.00 & 2.38 & 5.65 & 3.04 & 0.18 & -0.80 \\
\hline NG & 113.50 & 146.00 & 90.00 & 15.94 & 253.95 & 15.45 & 0.42 & -0.79 \\
\hline TGW & 18.26 & 24.70 & 14.10 & 2.25 & 5.07 & 2.48 & 0.78 & 0.52 \\
\hline SPY & 19.93 & 29.17 & 14.27 & 3.86 & 14.88 & 2.71 & 0.59 & -0.48 \\
\hline
\end{tabular}

Table. 3 Descriptive statistics in $\mathrm{BC}_{1} \mathrm{~F}_{1}$ cross TNAU CMS $2 \mathrm{~B} \times$ Zenith

\begin{tabular}{|c|c|c|c|c|c|c|c|c|}
\hline \multirow{2}{*}{ Variables } & \multirow{2}{*}{ Mean } & \multicolumn{2}{|c|}{ Range } & \multirow{2}{*}{$\begin{array}{c}\text { Standard } \\
\text { Deviation }\end{array}$} & \multirow{2}{*}{ Variance } & \multirow{2}{*}{$\begin{array}{l}\text { Standard } \\
\text { Error }\end{array}$} & \multirow{2}{*}{ Skewness } & \multirow{2}{*}{ Kurtosis } \\
\hline & & Max. & Min. & & & & & \\
\hline $\mathrm{PH}$ & 101.59 & 128.00 & 84.00 & 14.25 & 203.12 & 14.66 & 0.46 & -1.26 \\
\hline NPT & 7.85 & 13.00 & 3.00 & 2.01 & 4.04 & 1.13 & 0.21 & 0.48 \\
\hline PL & 21.86 & 27.00 & 17.00 & 2.69 & 7.21 & 3.16 & -0.37 & -0.78 \\
\hline NG & 100.46 & 190.00 & 77.00 & 18.98 & 360.34 & 14.50 & 2.36 & 9.53 \\
\hline TGW & 19.85 & 26.60 & 16.11 & 2.57 & 6.58 & 2.87 & 0.44 & -0.66 \\
\hline SPY & 20.64 & 28.89 & 16.20 & 3.03 & 9.17 & 2.98 & 0.78 & 0.19 \\
\hline
\end{tabular}

\section{TNAU CMS 2B $\times$ Zenith}

Mean variation was high for thousand grain weight (77.00-190.00) followed by plant height (84.00-128.00). This finding was line up with (Ameenal et al., 2016; Ponnaiah Govintharaj et al., 2016). Negative skewness was noticed only in panicle length and it explained that duplicate gene interaction plays major role (Lestari et al, 2015). Positive kurtosis was observed for number of productive tillers, numbers of grains and single plant yield were controlled by more genes and other examined characters were influenced by few genes, indicating that these were platykurtic distribution (Vishnu et al., 2014). Number of grains was distributed leptokurtic nature, which is controlled by few genes.

In conclusion, this study revealed that variability was exists in studied characters of all the crosses. Selection could be effective for panicle length, thousand grain weight and 
single plant yield would be gain higher genetic advance than expected at early stage of one or two crosses. Selection needs to be done at later generation for plant height, number of productive tillers and number of grains in all back crosses.

\section{References}

Fisher, R.A., F.R. Immer and Tedin, O. 1932. The genetical interpretation of statistics of the third degree in the study of quantitative inheritance. Genetics, 17:107-124.

Govintharaj, P., T. Shalini, S. Manonmani and Robin, S. 2016. Genetic parameters studies on bacterial blight resistance genes introgressed segregating population in Rice. World Scientific News, 59: 85-96.

Kiran, K.K. 2012. Genetic variability for grain yield, its components and inheritance of resistance to $\mathrm{BPH}$ in two $\mathrm{F}_{2}$ populations of rice (Oryza sativa L.). M.Sc., Thesis in University of Agricultural Sciences, GKVK, Bangalore.

Kotch, G.P., R. Ortiz and Ross W.M. 1992. Genetic analysis by use of potato haploid populations. Genome, 35:103-8.

Lestari, A.P., Suwarno, Trikoesoemaningtyas, D. Sopandie and Aswinnoor, H. 2015. Panicle Length and Weight Performance of $\mathrm{F}_{3}$ Population from Local and Introduction Hybridization of Rice Varieties. HAYATI J. Biosci., 22(2)-87-92.

Mallikarjuna, N.M. 2013. Genetic analysis and breeding potential for grain yield and its stabilizing traits under aerobic condition in Rice (Oryza sativa L.). M.Sc., Thesis in University of Agricultural Sciences,
GKVK, Bangalore.

Nachimuthu, V.V., S. Robin, D. Sudhakar, M. Raveendran, S. Rajeswari and Manonmani, S. Evaluation of Rice Genetic Diversity and Variability in a Population Panel by Principal Component Analysis. Indian J. Sci. Technol., 7(10): 1555-1562.

Ponnaiah Govintharaj, T. Shalini, S. Manonmani and Robin, S. 2016. Estimates of Genetic Variability, Heritability and Genetic Advance for Blast Resistance Gene Introgressed Segregating Population in Rice. Int. J. Curr. Microbiol. App. Sci., 5(12): 672-677.

Pooni, H.S., J.L. Jinks and Cornish, M.A. 1977. The causes and consequences of nonnormality in predicting the properties of recombinant inbred lines. Heredity, 38: 329-38.

Robson, D.S. 1956. Application of K4 statistics to genetic variance component analysis. Biometrics, 12: 433-44.

Roy, D. 2000. Analysis of skewness and kurtosis. In: Plant breeding -The Analysis and Exploitation of Variation. Narosa Publishing House. New Delhi. India. pp 300-304.

Tannidi, S., P. Govintharaj, M. Ameenal, S. Manonmani and Robin, S. 2016. Improving blast resistance in parental line of rice hybrid through marker assisted selection. Int. J. Agri. Sci. Res., 6(5): 339-346.

Vanitha, J., K. Amutha, R. Mahendran, J. Srinivasan, S. Robin and Usha kumari, R. 2016. Genetic variability studies for Zinc efficiency in aerobic rice. SABRAO J. Breeding and Genetics, 48(4): 425-433.

\section{How to cite this article:}

Ponnaiah Govintharaj, Shalini Tannidi, Manonmani Swaminathan, Robin Sabariappan, Vishnu Varthini Nachimuthu, Karthika Gunasekaran and Balaji Aravindhan. Genetic Variability for Yield and Yield Components Characters in Bacterial Blight and Blast Resistance Genes Introgressed Backcross Populations in Rice. Int.J.Curr.Microbiol.App.Sci. 6(2): 100-103. doi: http://dx.doi.org/10.20546/ijcmas.2017.602.014 